\title{
PEMBENTUKAN, PERKEMBANGAN DAN PEMBAHARUAN HUKUM ISLAM DALAM TINJAUAN ORIENTALIS
}

\author{
Fakhruddin \\ Fakultas Syari'ah UIN Maliki Malang \\ Telepon: (0341) 559399 \\ Email:fakhruddinsyarief@yahoo.co.id
}

\begin{abstract}
The development of Islamic law from its inception to its maturity has drawn a lot of attentions from some well known figures within Western scholars. Great names, such as Goldziher, Schacht, and Anderson, are among those who contribute the discourses on Islamic law in classical and modern period. While the first two scholars focus their research on Islamic law in the early phase of its development, the last one direct his study on its development in the modern period. The role of Quran and Sunnah on the development of Islamic law is under critical analysis of the Goldziher and Schacht, while the reform of it becomes the center of Anderson's study.

Perkembangan hukum Islam mengundang perhatian para tokoh pemikiran barat seperti Ignaz Goldziher, Schacht and Anderson. Mereka adalah tokoh-tokoh yang berkontribusi terhadap kajian-kajian hukum Islam pada periode klasik dan modern. sementara Goldziher dan schacth memfokuskan penelitian mereka pada hukum Islam pada fase awal perkembangannya, Anderson fokus pada hukum Islam periode modern. Peran al-Quran dan Sunnah terhadap perkembangan hukum Islam menjadi bahasan utama dari analisa kritis Goldziher dan Schacht sedangkan pembaharuan hukum Islam menjadi kajian Utama dari Anderson.
\end{abstract}

Keywords: Orientalis, Pembaharuan, Hukum Islam

\section{Pendahuluan}

Tulisan ini berusaha merangkum pokok pandangan kaum orientalis mengenai sejarah perkembangan hukum Islam hingga menjadi bentuk yang kita kenal sekarang. Dimulai dengan pandangan Goldziher tentang hukum Islam dan perkembangannya yang ia tuangkan dalam karyanya Introduction to Islam Law and Theology. Tulisan ini kemudian memaparkan kajian Schacht mengenai pembentukan dan perkembangan hukum Islam sejak abad klasik hingga abad pertengahan. Kajian Schacht sendiri, yang terekam secara utuh dalam dua karyanya, Introduction to Islamic Law dan The Origins of Muhammadan Juris- prudence, sebenarnya ditujukan untuk memperluas dan memperkuat tesis yang diajukan oleh Goldziher. Pandangan Schacht tentang asal-usul hukum Islam dan awal perkembangannya masih cukup signifikan dan juga masih dijadikan titik tolak penelitian hukum Islam di dunia Barat. Namun perlu digarisbawahi bahwa pengaruhnya tidak lagi sehebat dulu ketika ia masih hidup. Hal ini terbukti dengan banyaknya kritikan yang dilakukan oleh sarjana Muslim maupun kubu orientalis sendiri sejak diterbitkannya kedua karya monumental Schacht tersebut di atas. Kemudian, sebelum tiba pada kesimpulan, penulis juga memaparkan pandangan J.N.D. Ander- 
son tentang perkembangan hukum Islam pada masa modern. Pemaparan pemikiran Anderson tersebut dimaksudkan untuk menutupi kekosongan yang ditinggalkan oleh Schacht, yaitu perkembangan hukum Islam pada masa modern, mengingat kajian Schacht hanya berfokus pada perkembangan hukum Islam pada abad klasik dan pertengahan.

\section{Asal Usul Hukum Islam Menurut Goldziher}

Berbeda dengan dugaan beberapa kalangan yang menyatakan bahwa "Islam terlahir sebagai sebuah sistem yang bulat dan sempurna,". Kebulatan Islam, menurut Goldziher, jelas menunggu karya generasi Muslim berikutnya. ${ }^{1}$ Seiring dengan perluasan agama dan wilayah kekuasaan Islam yang sedemikian cepat, dasar-dasar administrasi negara untuk mengurusi perkembangan baru di wilayah taklukan mulai diletakkan. Masalah terbesar yang dihadapi para Muslim terdahulu adalah bagaimana hukum agama memberi jawaban atas persoalan yang timbul akibat persentuhan Islam dengan dunia luar yang telah memiliki alam pikiran yang berbeda dengan dunia Arab. Agama Islam sendiri menurut Goldziher tidak sengaja dipersiapkan untuk menghadapi keadaan yang jauh di luar batasbatas negeri tempat kelahirannya. ${ }^{2}$ Menurutnya, kerja keras dan pikiran Nabi hanya tertuju pada masalah dan kondisi mendesak yang beliau jumpai saat itu. Oleh karena itu seperti halnya gagasan-gagasan dalam alQuran, ketentuan yang digariskan Nabi saw bersifat khusus dan hanya terbatas pada milieu masyarakat primitif Arab. Beliau tidak memadai untuk menghadapi situasi baru dan tidak menjangkau peristiwa dan kondisi tak terduga yang disebabkan oleh perluasan dan penaklukan Islam. Seandainyapun ada, ketentuan itu hanya mengatur hal-hal pokok saja, dan itupun masih belum jelas dan mantap. ${ }^{3}$

Oleh karena itu pemikiran hukum Islam dan terbentuknya institusi Islam merupakan karya generasi Islam berikutnya, yang mun-

1 Ignaz Goldziher, Introduction to Islamic Theology and Law (New Jersey: Princeton University Press), h. 32.
Ibid., 31
${ }^{3}$ Ibid., 36.

cul bukan tanpa perdebatan internal dan sikap kompromi yang terjadi dalam tubuh masyarakat Islam sendiri.

Tak lama setelah Nabi saw wafat, perkembangan hukum Islam mulai diarahkan untuk memenuhi kebutuhan hukum di wilayahwilayah taklukan. Untuk itu di Syria, Mesir dan Persia, orang-orang Muslim segera mengadopsi adat budaya lokal yang berakar pada peradaban kuno setempat yang sama sekali asing bagi para penakluk Arab ketika itu. $^{4}$ Goldziher menyatakan bahwa umat Islam saat itu, terutama pada masa dinasti Umayyah, tidak ingin dipusingkan oleh urusan penyusunan undang-undang Islam yang orisinil, tapi lebih banyak mengurusi masalah konsolidasi politik kenegaraan sehingga untuk menghadapi situasi baru, para qadi hanya bersandar pada kebiasaan setempat, kebijakan dan terkadang putusan yang arbitrer. ${ }^{5}$

Situasi ini tidak memuaskan sebagian orang Islam yang ingin membangun kehidupan dunia sesuai dengan cita-cita agama. Mereka menekankan bahwa bidang kehidupan yang sakral maupun yang profan harus didasarkan pada garis kebijakan Nabi saw yang dapat diketahui lewat penuturan para sahabat yang bertemu langsung dengan Nabi saw dan mengetahui perilaku dan keputusan beliau. Untuk itu semua tindakan atau keputusan baru diterima dan dipandang benar jika ia didukung oleh periwayatan sahabat, yang menjamin bahwa hal itu memang sesuai dengan kehendak Nabi saw. Melalui otoritas para sahabat, praktik tertentu dalam Islam memperoleh kekuataan hukum. Praktik-praktik tersebut disebut sebagai sunah atau tradisi keagamaan. Adapun bentuk verbal dari tradisi tersebut dinamakan hadis. Dengan kata lain, hadis adalah dokumentasi tentang sunah. ${ }^{6}$ Karena sunah adalah perwujudan pandangan dan praktik umat Islam terdahulu, maka ia berfungsi sebagai penjelas paling otoritatif atas alQuran. Ayat-ayat al-Quran baru hidup dan mempunyai daya setelah ditafsirkan oleh sunah.

\footnotetext{
${ }^{4}$ Ibid., 36.

5 Ibid., 37.

${ }^{6}$ Ibid., 38
} 
Namun orang-orang Islam terdahulupun telah menyadari adanya kemungkinan bahwa hadis-hadis yang diriwayatkan oleh generasi-generasi sebelumnya terkadang mengandung bahan-bahan yang bukan berasal langsung dari Nabi saw, tapi berasal dari tokoh-tokoh Muslim klasik terkemuka. Dengan semakin jauhnya jarak dari masa hidup Nabi saw, bahaya lain mulai mengancam hadis, yaitu bahwa orang akan membuat-buat sanad fiktif yang dinyatakan bersambung hingga sahabat dan Nabi saw untuk sekedar memperkuat dan melegitimasi doktrin mereka. Hal ini terbukti dengan adanya fenomena pembengkakan jumlah hadis, karena hampir setiap doktrin teoritis yang dianut atau yang ditentang oleh sebuah kelompok keagamaan atau politis, bahkan dua buah ajaran yang saling bertentangan sekalipun, memiliki dokumentasi had is tersendiri dengan sanad yang lengkap. ${ }^{7}$ Oleh karena itu para pakar hadis mulai meneliti keotentikan hadis dengan memisahkan hadis-hadis shahih dari hadis-hadis fiktif. Disiplin ilmu ini dinamakan ilmu kritik hadis, yang mencapai puncaknya pada abad ke-3 hijrah ketika enam kitab hadis (kutub alsittah) diposisikan sebagai sumber pengambilan hukum-dua diantaranya, yaitu koleksi hadis Bukhari (w. 256/870) dan Muslim (w.261/875), paling diakui otoritasnya-yang memuat hadis-hadis pilihan yang disaring dari sekian banyak hadis fiktif. Namun, menurut Goldziher, metode "modern" kritik hadis yang dianut oleh kesarjanaan Barat, dimana ia merupakan seorang perintis pertamanya, berbeda dengan metode kritik hadis yang digunakan oleh pakar hadis Muslim ortodoks, oleh karena itu kesimpulan akhir yang dicapai oleh kedua metode tersebut seringkali berbeda, dimana sebuah hadis yang dikatakan otentik oleh metode klasik Muslim, acapkali justru diragukan keotentikannya oleh metode kritik hadis "modern" orientalis. ${ }^{8}$

Goldziher tidak mempermasalahkan lebih lanjut tentang bentuk akhir hadis, karena menurutnya penelitian tentang perkembangan hadis dalam konteks kesejarahannya justru sangat penting untuk mengungkap evolusi agama Islam, mengingat tidak saja hukum dan adat istiadat setempat, namun doktrin teologi dan politikpun diketahui telah mengambil bentuk hadis. Berbagai gagasan asing yang diserap ke dalam Islam sering terlahir kembali dalam bentuk sebuah hadis, hingga bentuk aslinya tidak bisa lagi dikenali. ${ }^{9}$ Dengan cara seperti inilah hadis membentuk kerangka awal pemikiran hukum dalam Islam. Oleh karena itu, menurut Goldziher, tidak aneh bila pengaruh budaya asing kemudian berdampak pada evolusi hukum Islam. Yurisprudensi Islam dengan jelas memperlihatkan adanya pengaruh hukum Romawi, baik dalam metode maupun ketentuan substantifnya. ${ }^{10}$

Perkembangan selanjutnya dalam fiqh Is lam terjadi setelah revolusi Abbasiyah yang berhasil menggulingkan dinasti Umayyah. Berbeda dengan dinasti sebelumnya yang cenderung menghidupkan gagasan dan tradisi Arab kuno dalam pemerintahannya, dinasti Abbasiyah mengklaim sebagai pendukung sunah Nabi saw, dengan hukum agama sebagai satu-satunya haluan kebijakan. Dengan mengklaim sebagai keturunan keluarga Nabi saw, dinasti Abbasiyah memperlihatkan sikap penghormatan yang berlebihan terhadap Nabi saw, dan tampak memamerkan sikap mereka yang berbeda dengan sikap dinasti sebelumnya. ${ }^{11}$ Oleh karena itu usaha-usaha untuk mempelajari hadis sebagai sumber hukum agama mendapat perhatian yang serius; tidak hanya dipandang sekedar amal shaleh, tapi merupakan persoalan yang memiliki kepentingan praktis yang luar biasa. Bukan saja ketentuan mengenai aspek kehidupan ritual semata, tapi juga institusi pemerintahan mulai didasarkan pada hukum agama. Administrasi peradilan dan segala macam transaksi, hingga hukum sipil yang paling sederhana sekalipun, harus memenuhi ketentuan agama. Berawal dari bentuknya yang sederhana, pada periode ini hukum Islam berkembang dengan subur

\footnotetext{
9 Ibid., 40.

10 Ibid., 44.

11 Ibid., 46.
} 
dan pesat. Periode ini disebut juga dengan "periode fiqh dan fuqaha.","

Di bawah perlindungan pemerintahan teokratik Abbasiyah, pusat-pusat studi fiqh bermunculan. Hadis disebarluaskan dan peraturan baru yang dideduksi darinya mulai disimpulkan, dengan hasil yang kadang-kadang saling bertentangan karena perbedaan pandangan dan metode yang digunakan. Kecenderungan yang berbeda ini membantu munculnya mazhab-mazhab hukum klasik yang berbeda, baik dalam rincian hukum substantif maupun metode penalarannya. Namun dari sekian banyak mazhab hukum ortodoksi, hanya empat mazhab yang bertahan hingga sekarang. Dominasi sebuah mazhab pada sebuah wilayah banyak ditentukan oleh kewibawaan seorang figur ahli hukum dan para pengikutnya. ${ }^{13}$

Prinsip terakhir hukum Islam yang sangat penting dan memberikan karakter khusus terhadap perkembangan hukum Islam adalah ijma. Bagi Goldziher, ijma merupakan sarana untuk mengakhiri perbedaan pandangan di antara begitu banyak mazhab hukum klasik. Prinsip ini memperoleh legitimasinya dari sebuah ungkapan yang dikatakan berasal dari Nabi: "Umatku tidak akan bersepakat dalam berbuat kesalahan (dhalalah)." Konsekuensinya, apapun yang diterima dan disetujui oleh seluruh masyarakat Islam harus dipandang sebagai sesuatu yang benar. Berbeda sikap dan pendapat dengan ijma berarti telah keluar dari lingkungan masyarakat Muslim. Dengan demikian ijma, menurut Goldziher, merupakan otoritas legalitas yang paling penting dalam sistem hukum Islam klasik. ${ }^{14}$

\section{Pembentukan dan Perkembangan Hukum Islam Menurut Joseph Schacht}

Perkembangan sejarah hukum Islam dan peran Syafi'i dalam pembentukannya merupakan perhatian utama Schacht. Menurutnya, Syafi'i adalah tokoh utama yang telah membangun prinsip-prinsip dasar hukum Islam dan yang pertama menyusun sebuah ki-

\footnotetext{
12 Ibid., 47.

13 Ibid., 49.

14 Ibid., 51.
}

tab tentang teori hukum Islam, dengan mengatakan bahwa: pernyataan yang menyebutkan bahwa Abu Yusuf merupakan orang yang pertama kali menghimpun kitab mengenai teori hukum berdasarkan doktrin Abu Hanifah, tidak didukung oleh sumber-sumber klasik. $^{15}$

Menurut Schacht, pada masa-masa awal Islam hukum Islam seperti yang kita kenal sekarang belum terbentuk. ${ }^{16}$ Muhammad tidak bertujuan membangun sistem hukum yang berdiri sendiri. Schacht berargumen bahwa Muhammad tidak punya cukup alasan untuk merubah hukum adat yang telah berlaku saat itu sebab menurut Schacht, tujuan misi Muhammad adalah bukan untuk menciptakan sistem hukum baru, tapi ia bertujuan untuk mendidik manusia bagaimana mereka harus bersikap, apa yang harus mereka lakukan, dan apa yang harus dijauhi agar selamat dalam hisab di akhirat kelak dan masuk ke surga. Oleh karena itulah Islam secara umum dan hukum Islam secara khusus merupakan sistem kewajiban (a system of duties), yang mencakup kewajiban ibadah, hukum dan etika dalam satu wadah, dan meletakkan semua bentuk kewajiban itu dalam otoritas keagamaan yang sama. Jika standar keagamaan dan etika telah sepenuhnya diterapkan atas semua aspek perilaku manusia, dan jika mereka secara konsisten menerapkannya dalam praktik, tidak ada lagi ruang dan kebutuhan untuk menciptakan sistem hukum dalam maknanya yang sempit. ${ }^{17}$

Lebih lanjut Schacht menyatakan bahwa Muhammad menjalankan kekuasaannya di luar sistem hukum yang ada; bagi orang yang beriman, otoritasnya tidak bersifat legal, tapi bersifat keagamaan, dan bagi seorang awam otoritasnya bersifat politis. ${ }^{18}$ Dalam konteks ini, peran sunah sebagai sumber hukum Islam pada masa formatifnya merupakan kajian serius bagi Schacht. Melalui pendeka-

15 Joseph Schacht, The Origins of Muhammadan Jurisprudence, (Oxford: Clarendon Press, 1979), h. 133.

16 Joseph Schacht, Pengantar Hukum Islam, Terj. Moh. Said dkk (Jakarta: Depag RI, 1995), h. 40.

17 Ibid.

18 Ibid. 
tan historis terhadap sunah, Schacht meneliti terma sunah seperti yang umum digunakan oleh masyarakat Arab masa pra-Islam, masa awal Islam dan masa Syafi' i, terutama dalam kaitannya dengan konsep sunnah nabi.

Dari hasil analisanya atas sekumpulan literatur klasik, ia tiba pada kesimpulan bahwa terma sunah biasa digunakan pada masa pra-Islam dalam arti kebiasaan masyarakat yang diriwayatkan turun temurun secara lisan. Menurutnya al-Qur'an sendiri menyebutkan bahwa prinsip-prinsip moral yang dijadikan pegangan pada masa pra-Islam merupakan sunah orang-orang Arab yang diriwayatkan secara lisan dari nenek moyang mereka. ${ }^{19}$ Oleh karena itu tidaklah aneh jika dikatakan bahwa hukum Islam memiliki akar sejarah dalam tradisi Arab pra-Islam. Tesis Schacht ini juga diperkuat oleh hasil analisa dari Toshihiko Izutsu yang menyatakan bahwa:

Kita akan bersikap tidak adil terhadap peninggalan masa Jahiliyah dan juga terhadap posisi Islam sendiri jika kita mengatakan bahwa Islam menyangkal dan menolak apapun bentuk gagasan moral yang berasal dari masyarakat Arab pra-Islam sebagai sebuah gagasan yang tidak selaras dengan konsep tauhid. Jelas terdapat adanya keterkaitan tertentu antara pandangan al-Qur'an dengan pandangan dunia Arab klasik, sebagaimana terdapat juga kesenjangan di antara dua pandangan tersebut.

Beberapa nilai pra-Islam sepenuhnya ditolak oleh al-Qur'an. Namun kebanyakan nilai-nilai tersebut diterima, dimodifikasi, dan dikembangkan, sesuai dengan tuntutan agama baru ini. Jadi, pandangan lama yang dirubah wujud aslinya dan sepenuhnya dipisahkan dari gaya kesukuan tradisional Arab dilahirkan kembali sebagai sebuah bentuk nilai etika keagamaan yang baru, dan pada akhirnya membentuk bagian integral sistem Islam. ${ }^{20}$

Gagasan pra-Islam tentang sunah kembali menegaskan dirinya dalam Islam. Hal ini

${ }^{19}$ Lihat QS. 2:170 dan QS. 43:21-24.

20 Toshihiko Izutsu, Konsep-Konsep Etik Religius dalam al-Qur'an, Terj. Agus Fahri Husein dkk. (Yogyakarta: Tiara Wacana, 2003), h. 89. dapat dilihat dalam beberapa institusi hukum dalam Islam yang mewakili keberlangsungan tradisi Arab pra-Islam, seperti poligami, perceraian, zihar dan hakam.

Seperti kita ketahui, di kalangan orienttalis Goldziher merupakan perintis metode kritik hadis modern. Menurutnya, sunah adalah perwujudan dari pandangan dan praktik yang berasal dari masyarakat Islam terdahulu. Adapun bentuk formal dari sunah dinamakan dengan hadis. Tesis Goldziher tentang hadis kemudian dikembangkan oleh Schacht, yang menyatakan bahwa kesimpulannya seputar hadis hanyalah memperkuat dan mengembangkan tesis yang disusun oleh Goldziher.

Terma sunah mengalami perluasan makna sejalan dengan meluasnya wilayah kekuasaan Islam. Di wilayah-wilayah baru dengan adat dan budaya yang baru, Islam membuktikan dirinya sebagai sebuah agama yang fleksibel. Beberapa praktik hukum dan administrasi dari berbagai daerah baru perlahan- lahan tapi pasti mulai diadopsi ke dalam sistem agama Islam. Dalam konteks ini, Schacht mengomentari sikap orang-orang Islam saat itu dengan pernyataannya: "Sepanjang tidak ada hambatan moral keagamaan atas bentuk-bentuk transaksi dan perilaku tertentu, orangorang Islam tidak memperdulikan aspek teknis sebuah hukum." 21 Oleh karena itu terma sunah tersebut kemudian bercampur dengan sunah-sunah di wilayah taklukan.

Pada masa pemerintahan Umayyah, sunah kembali mengalami perubahan makna. Mazhab-mazhab hukum klasik, kaum Ahl alHadits, dan Syafi'i merupakan pihak-pihak yang terlibat dalam diskursus tentang sunah. Pada masa itu sunah masih berarti 'living tradition' (tradisi yang hidup) seperti yang terekam dalam doktrin mazhab- mazhab hukum klasik dan belum berbentuk hadis seperti yang kita kenal sekarang. Kesinambungan perkembangan doktrin mazhab-mazhab hukum kemudian terkalahkan oleh laju partumbuhan hadis, terutama hadis Nabi, dan akhirnya membuat mazhab-mazhab hukum berada dalam posisi bertahan terhadap arus pasang

${ }^{21}$ Schacht, Pengantar..., h. 69. 
perkembangan hadis ketika Syafi' i muncul. ${ }^{22}$ Menurut kaum Ahl al-Hadis, konsep hadis nabi mulai menggantikan konsep 'tradisi yang hidup' dalam mazhab hukum klasik. Pada masa inilah hadis-hadis yang dikatakan berasal dari nabi mulai bermunculan, yang dilengkapi dengan sanad bersambung yang terdiri dari orang-orang yang terpercaya. Melalui kritik sanad, Schacht tiba pada kesimpulan yang membuat "merah telinga" para pakar hadis dari kalangan Muslim. Menurutnya, rangkaian sanad hadis yang diproyeksikan kebelakang (projected back), yaitu ke masa Nabi, baru dipopulerkan secara luas pada sekitar abad kedua hijrah, yaitu sepanjang pecahnya revolusi Abbasiyah, ${ }^{23}$ sehingga tidak ada alasan untuk beranggapan bahwa praktik umum penggunaan sanad muncul sebelum awal abad kedua hijrah.

Masa pemerintahan Umayyah merupakan periode Islamisasi hukum yang berlangsung hingga awal periode penyusunan kitabkitab hadis. ${ }^{24}$ Secara sistematis, Schacht menguraikan sejarah perkembangan pemikiran hukum Islam dari masa pra-Umayyah hingga masa Syafi'i, ketika konsep tentang hukum Islam telah mencapai bentuk finalnya.

Menurut teori hukum Islam klasik, sumber utama hukum Islam adalah al-Qur'an, sunah, ijma, dan qiyas. Meskipun Schacht mengakui konsep tersebut, ia menyatakan bahwa secara historis al-Qur'an dan Hadis bukanlah sumber hukum pertama, tapi merupakan sumber hukum yang datang belakangan. Menurutnya, yang lebih menarik lagi adalah kenyataan bahwa dalam berbagai kasus, praktik hukum pada masa awal Islam telah menyimpang dari ketentuan harfiah alQur'an. ${ }^{25}$ Selanjutnya ia menyatakan bahwa Irak adalah pusat kegiatan teorisasi dan sistematisasi praktik-praktik administratif pemerintahan Umayyah. Aktifitas ini dilakukan oleh para qadi yang dipilih dan diangkat oleh khalifah untuk menyelesaikan persoalah hukum di berbagai provinsi. Teori dan metode

\footnotetext{
22 Ibid., h. 79

23 Ibid., h. 47

24 Ibid., h. 41

25 Ibid., h. 75
}

penalaran hukum mazhab Irak adalah yang paling maju dibandingkan dengan mazhabmazhab hukum lainnya. Mengenai sunah, Schacht berpendapat bahwa sunah yang hidup pada masa nabi merupakan salah satu sumber hukum untuk menyelesaikan permasalahan yang terjadi dalam komunitas Muslim, dan kemudian menjadi 'salah satu konsep utama hukum Islam'. ${ }^{26}$ Sunah kemudian menjadi salah satu faktor terpenting pada masa pembentukan hukum Islam (formative period), sedemikian rupa sehingga ayat-ayat alQuran tertentu tampak diabaikan.

Untuk menyelesaikan persoalan di berbagai wilayah Islam, Khalifah memilih dan mengangkat para qadi. Selain adat istiadat di tempat mereka bertugas, praktik masyarakat dan peraturan administratif pemerintahan Umayah, yang ditafsirkan oleh mereka dengan menggunakan $r a$ 'y, kemudian dipandang sebagai sumber penting yang digunakan untuk menangani masalah hukum. Karena para qadi tersebut adalah pegawai pemerintahan Umayyah, keputusan-keputusan mereka akhirnya menjadi dasar dari apa yang kita kenal sekarang sebagai hukum Islam. Pada masa inilah teorisasi, sistematisasi dan islamisasi hukum mulai dilakukan dengan serius. Para qadi yang jumlahnya terus bertambah itu kemudian menyatukan diri ke dalam sebuah mazhab hukum klasik yang didasarkan pada letak geografis, seperti mazhab Irak, Basrah, Madinah, Mekah dan Syria. Akibatnya praktik populer administratif pada masa pemerintahan Umayyah kemudian diadopsi sebagai hukum Is lam. Pada masa itu gagasan tentang praktik komunitas Muslim kemudian diserap menjadi doktrin mazhab yang disebut dengan "praktik yang hidup" (living tradition). Praktik tersebut pada akhirnya menggantikan konsep sunah yang telah ada sebelumnya dan menjadi salah satu sumber hukum Is lam.

Segera setelah masa Syafi'i, watak kedaerahan dari mazhab-mazhab hukum klasik sedikit demi sedikit menghilang dan beralih menjadi mazhab yang didasarkan pada figur tertentu. Akibatnya setelah melewati berbagai perkembangan, mazhab Kufah mengkristal

${ }^{26}$ Ibid., h. 78. 
menjadi mazhab Hanafi, dan mazhab Madinah menjadi mazhab Maliki. ${ }^{27}$ Keterlibatan Syafi'i dalam proses pematangan konsep hukum Islam turut membantu terbentuknya mazhab hukum atas namanya sendiri. ${ }^{28} \mathrm{Ke}$ munculan doktrin mazhab Syafi'i ini hingga taraf tertentu ternyata mengundang konflik, terutama dengan kelompok Ahl al-Hadis. Berbeda dengan doktrin Syafi'i, kaum Ahl alHadis sangat mengkritik segala bentuk penalaran logika, dan sepenuhnya bersandar pada hadis, sedemikian rupa sehingga mereka lebih menyukai hadis yang lemah dari pada analisa logika yang kuat. Mereka menyandarkan doktrin-doktrin mereka kepada seorang tokoh Ahl al-Hadis terkemuka, Ibn Hanbal, yang kemudian dikenal sebagai pendiri mazhab Hanbali. ${ }^{29}$

Menjelang akhir pemerintahan Umayyah, gerakan-gerakan keagamaan muncul dan menggugat kebijakan Umayyah sebagai kebijakan sekuler yang menyimpang dari ketentuan agama sehingga, menurut mereka, perlu dilakukan usaha serius untuk menerapkan doktrin agama dalam kehidupan sosial dan politik. Dalam konteks inilah proses islamisasi hukum selanjutnya dilakukan dengan lebih sistematis. Al-Qur'an lebih sering dijadikan rujukan dalam memecahkan persoalan hukum, dan makna sunah dibatasi penggunaannya hanya pada perilaku, perkataaan dan persetujuan Nabi saja. ${ }^{30}$

Puncak perkembangan sistematisasi hukum Islam dan islamisasi hukum Islam terjadi sepenuhnya di tangan Syafi' ${ }^{31}{ }^{31}$ Dalam teorinya tentang sumber-sumber hukum Islam, yaitu al-Qur'an, sunah, ijma dan qiyas, terlihat bahwa ia tidak memasukkan praktik populer komunitas Muslim, yang merupakan "tradisi yang hidup" yang dianut oleh mazhab- mazhab hukum klasik, sebagai acuan dalam menetapkan hukum. ${ }^{32}$ Terhadap sumber hukum terakhir, yaitu qiyas, Syafi'i hanya

\footnotetext{
27 Ibid., h. 81.

28 Ibid., h. 48.

${ }^{29}$ Ibid., h. 56.

30 Ibid., h. 57.

31 Ibid.

32 Ibid., h. 93.
}

mengakui qiyas yang dilakukan dengan ketat mengikuti prinsip penalaran logika yang sistematis, yaitu dengan menggunakan qiyas sebagai satu-satunya bentuk penalaran untuk melakukan istinbat hukum dari tiga sumber terdahulu. ${ }^{33}$ Usaha Syafi'i ini, yang merupakan bentuk final dari proses perkembangan sumber-sumber hukum Islam secara khusus dan hukum Islam secara umum, dipandang sebagai sebuah sistem yang benar-benar konsisten dan lebih unggul daripada doktrin mazhab-mazhab hukum klasik. Namun Schacht mengingatkan bahwa upaya sistematis ini dalam jangka panjang justru akan mengakibatkan kehilangan kelenturannya dan akhirnya akan membuatnya semakin kaku. Mengenai hal ini Schacht berpendapat:

Petunjuk awal tentang sikap penolakan terhadap kebebasan ulama-ulama masa itu dalam melakukan penalaran, seperti yang dinikmati para pendahulu mereka, terlihat dalam tulisan Syafi'i, dan kira-kira sejak abad ke-3 Hijriah (abad ke-6 Masehi) ide tersebut mulai mendapat tempat hingga hanya ulama-ulama besar masa lalu saja yang tak tertandingi dan juga bukan pengekor- yang memiliki hak untuk melakukan ijtihad. Pada masa itu istilah ijtihad tidak lagi terkait dengan ra'y, dan terbatas pada penarikan kesimpulan dari al-Qur'an, sunah nabi, dan ijma, dengan sebuah analogi dan penalaran sistematis. ${ }^{34}$

Dengan tercapainya finalitas hukum Islam, Schacht sepakat dengan pendapat kebanyakan orientalis sebelumnya tentang tertutupnya pintu ijtihad (insidad bab al-ijtihad), dengan menyatakan bahwa:

Pada awal abad ke-4 Hijriah (sekitar tahun 900 Masehi) tercapai sebuah titik di mana para ulama dari seluruh mazhab merasa bahwa seluruh persoalan penting telah dibahas secara menyeluruh dan telah memperoleh keputusan final, sehingga secara bertahap sebuah ijma dengan sendirinya terbentuk, yang berarti bahwa sejak saat itu tak seorangpun dipandang memenuhi syarat-syarat yang diperlukan untuk melaku-

33 J. N. D. Anderson, Islamic Law in the Modern World (New York: New York University Press) h. 2, 4, 51 .

34 Ibid., h. 2-3. 
kan ijtihad dalam hukum, dan bahwa seluruh aktifitas masa-masa selanjutnya dibatasi hanya pada penjelasan [syarah], penerapan, dan lebih sering lagi, penafsiran atas doktrin yang telah ditetapkan sekali untuk selamanya. "Tertutupnya pintu ijtihad" ini adalah istilah baku yang biasa dipakai, berpuncak pada tuntutan untuk melakukan taqlid; sebuah istilah yang mulanya bermakna semacam rujukan pada sahabat nabi yang biasa dilakukan oleh mazhab-mazhab hukum klasik, dan sekarang maknanya menjadi sebuah penerimaan total terhadap doktrin yang dianut oleh mazhab dan tokoh otor itatif. $^{35}$

\section{Pembaharuan Hukum Islam Menurut J.N. D. Anderson}

Sebagaimana halnya kaum orientalis lainnya, James Norman Dalrymple Anderson juga berpendapat bahwa konsep hukum dalam Islam sangat berbeda dengan konsep hukum yang dipahami oleh masyarakat Barat modern. ${ }^{36}$ Dalam pandangan dunia Barat hukum merupakan hasil karya manusia untuk mengatur kehidupan sosial, dan menjadikan akal dan kehendak manusia sebagai sumber hukum yang paling otoritatif. Dalam hal ini masyarakat sangat berperan dalam pembentukan hukum, sehingga hukum merefleksikan dengan jelas nilai-nilai yang berlaku dalam sebuah masyarakat dalam ruang lingkup waktu dan masa tertentu. Karena dibentuk oleh dan untuk kepentingan masyarakat, maka hukum berubah mengikuti kepentingan masyarakat yang melahirkannya. ${ }^{37}$ Sementara itu, hukum dalam paradigma Islam merupakan wahyu tuhan yang sekaligus merupakan sumber utamanya (Syâri), dan manusia sama sekali tidak memiliki kekuasaan legislatif. ${ }^{38}$ Hukum lahir secara ahistoris, universal dan kebal terhadap segala perubahan (immutable). Disamping sifatnya yang religious dan divi$n e$, cakupan hukum Islam juga meliputi halhal yang berada di luar bidang hukum yang dipahami oleh konsep Barat modern, karena

35 J. N. D. Anderson, Law Reform in the Muslim World (London: The Athlone Press), h. 38.

36 Anders on, Islamic Law..., h. 5, 17, 38.

37 Anders on, Law Reform..., h. 1.

38 Ibid., h. 14. hukum Islam tidak hanya mencakup bidangbidang yang pure hukum, tapi juga keseluruhan aspek hidup manusia. ${ }^{39}$ Oleh karena itu Anderson sangat meyakini posisi sentral hukum Islam dalam masyarakat Muslim. Peradaban Islam, menurutnya, dibangun di atas dasar agama dan agama Islam memberikan tempat yang amat penting terhadap hukum. Dengan demikian, tidak mungkin kita dapat memahami alam pikiran, cita-cita, politik, dan kond isi masyarakat Is lam tanpa memahami hukum Islam dengan baik. ${ }^{40}$

Walaupun fokus utama Anderson adalah perkembangan hukum Islam pada masa modern, ia juga tidak melewatkan begitu saja pembahasan tentang hukum Islam baik pada masa formatif, yaitu ketika hukum Islam masih sangat lentur dan adaptif terhadap hukum dan adat kebiasaan lokal, maupun pada masa klasik, yaitu ketika munculnya beragam mazhab hukum Islam ortodoks yang bertanggung jawab terhadap stagnasi hukum Islam. Menurut Anderson, pada periode kedua ini hukum Is lam menjadi semakin kaku dan statis, yang pada gilirannya, sebagai sebuah fait accompli, menimbulkan akibat yang tidak dikehendaki, yaitu tertutupnya pintu ijtihad.

Masa modern perkembangan hukum Islam menurut Anderson dimulai ketika negara bangsa (nation-state) mulai terbentuk di dunia Islam bersamaan dengan tumbuhnya kesadaran tentang adanya suatu pembaharuan hukum. ${ }^{41}$ Pembaharuan hukum Islam yang terjadi di berbagai negara bangsa Muslim ini berlangsung dalam dua tahap proses perkembangan, yang keduanya jelas menunjukkan kuatnya pengaruh peradaban Barat terhadap dunia Timur umumnya dan dunia Islam khususnya, terutama setelah revolusi Prancis.

Akibatnya, banyak aspek ajaran agama Is lam yang mulai dipertanyakan legalitas, validitas dan sentralitasnya, tidak terkecuali peran hukum Islam, termasuk juga wilayah hukum keluarga. Anderson meyakini bahwa sumber pendorong dan inspirasi dari gerakan

\footnotetext{
39 Anders on, Islamic Law..., h. 23-24.

40 J. N. D. Anderson, "Recent Development in Shari'ah Law," dalam Muslim World 40 (1950), h. 34.

41 Anderson, Law Reform..., h. 14-15.
} 
pembaharuan ini bukan berasal dari dunia Muslim, namun datang dari kekuatan eksternal umat, yaitu terutama dari kegiatan misionaris Kristen, dan dampak kemajuan kehidupan dan peradaban Barat secara umum.

Langkah awal modernisasi hukum Islam muncul ketika kebutuhan terhadap pranata hukum di negara-negara Muslim modern tidak dapat lagi terpenuhi hanya dengan materi-materi hukum Islam klasik. Kebanyakan doktrin hukum klasik telah kehilangan relevansinya dengan perkembangan dunia modern. ${ }^{42}$ Tidak diragukan lagi bahwa Turki Usmani adalah negara Muslim modern pertama yang melakukan pembaharuan dengan cara mengadopsi ide-ide Barat, termasuk di dalamnya sistem hukum, namun, seperti yang dikatakan Anderson, mereka tetap kuat berpegang pada agama Islam. ${ }^{43}$ Hasil reformasi hukum ini terlihat dalam wilayah hukum perdata, yaitu dengan dikeluarkannya Penal Code pada tahun 1858, Code of Personal Procedure tahun 1862, dan Code of Maritime Commerce tahun 1863. Tentang perundangundangan ini Anderson berkomentar bahwa dorongan bagi proses pembaharuan ini tidak muncul dari kehendak rakyat (bottom-up) tapi justru datang dari pemerintah (top-down) yang menginginkan efisiensi administrasi pemerintahan. ${ }^{44}$ Pada tahap perkembangan ini, reformasi hukum dilakukan tanpa menyentuh dan mencampuri ketentuan-ketentuan hukum Islam yang ada. Para reformis hanya melakukan legislasi hukum dari sumber lain, ${ }^{45}$ sambil mengklaim bahwa perundangundangan tersebut yang nyata didasarkan pada perundang-undangan model Barat adalah suplemen atas hukum Islam dan tidak dimaksudkan untuk menandingi hukum Islam. ${ }^{46}$ Sepanjang periode ini, para reformis tidak melakukan pembaharuan dalam wilayah hukum kekeluargaan, karena hukum ini dipandang sebagai jantung hukum Islam yang harus di-

42 Ibid., h. 42

43 Anderson, Islamic Law..., h. 21.

44 Anderson, Law Reform..., h. 38.

45 Anderson, "Recent Development..." dalam

The Muslim World 40, h. 38

${ }^{46}$ Anderson, Law Reform..., h. 43. pertahankan corak khas keislamannya, dan merupakan satu-satunya ketentuan hukum yang diterapkan secara murni dan utuh dalam praktik kehidupan. ${ }^{47}$ Namun sejak sekitar tahun 1915, corak pembaharuan semacam ini mulai berubah. Dengan pesatnya perkembangan kehidupan pada awal abad ke-20, pembaharuan atas hukum kekeluargaan Islam tidak bisa lagi dihindari. ${ }^{48}$ Anderson menyebut periode ini sebagai pembaharuan hukum tahap kedua. Kali ini para pembaharu berhadapan dengan sebuah persoalan penting tentang bagaimana melakukan pembaharuan terhadap hukum Islam itu sendiri. ${ }^{49}$ Pada tahap kedua ini para reformis tidak lagi mengadopsi sumber-sumber Barat, tapi justru mencarinya dari sumber-sumber budaya masyarakat mereka sendiri. ${ }^{50}$ Di antara hasil yang dicapai oleh gerakan pembaharuan hukum kekeluargaan Islam adalah keputusan pemerintah Turki Usmani tahun 1915 tentang perlindungan terhadap isteri yang diterlantarkan suaminya dan pemutusan hubungan pernikahan ketika suami menderita penyakit yang membahayakan kelangsungan kehidupan pernikahan. ${ }^{51}$ Dua tahun kemudian, kembali dikeluarkan undang-undang yang lebih bersifat reformis, yaitu undang-undang tentang Hak Keluarga.

Aspek lain tentang pembaharuan hukum Islam yang dibahas Anderson adalah mengenai problem dan prospek yang dihadapi para reformis di berbagai negara Muslim modern. Disamping itu Anderson juga membahas pandangan-pandangan berbeda yang dianut oleh para pembaharu dalam menyikapi gerakan pembaharuan hukum Islam, yang ia bagi ke dalam tiga kelompok besar, yaitu mereka yang ingin kembali kepada hukum Islam yang sejati, mereka yang menghendaki pelonggaran atas cakupan hukum Islam, dan mereka yang melakukan pendekatan yang lebih radikal terhadap seluruh tatanan hukum Islam. Dengan kata lain terdapat kelompok

\footnotetext{
47 Anderson, Islamic Law..., h. 82.

48 Ibid., h. 26.

49 J. N. D. Anderson, "Recent Development in
} Shari'ah Law," dalam Muslim World 41 (1951), h. 116.

\footnotetext{
${ }^{50}$ Anderson, Law Reform..., h. 172.

51 Anderson, Islamic Law..., h. 83.
} 
yang ingin menerapkan hukum Islam secara fundamental, kelompok yang berusaha melakukan kompromi antara dua kutub yang ekstrim, dan kelompok yang sepenuhnya ingin menanggalkan hukum Islam dan menggantinya dengan hukum sekuler.

Secara umum dapat dikatakan bahwa berbagai perkembangan di dunia Islam modern menunjukkan adanya kecenderungan ke arah pembaharuan beberapa ketentuan hukum Islam. Dalam melakukan pembaharuan tersebut para pembaharu berusaha menciptakan sebuah sistem hukum yang didasarkan bukan saja pada doktrin hukum klasik, tapi juga pada sumber-sumber asing, terutama dari Barat, yang selaras dengan prinsip-prinsip dasar hukum Islam, sehingga sistem hukum tersebut diharapkan mampu memenuhi kebutuhan dunia modern. Dalam konteks ini, Anderson membuat komentar tentang masa depan Islam secara umum dan hukum Islam secara khusus, bahwa keseluruhan bangunan Islam sebagai sistem keagamaan, sosial dan politik di masa depan ditentukan oleh sejauh mana para pembaharu dapat menyelesaikan konflik yang muncul akibat adanya kehendak untuk menyesuaikan doktrin hukum dengan realitas dan kebutuhan dunia modern.

\section{Penutup}

Kajian kaum orientalis mengenai sejarah dan perkembangan hukum Islam, yang dimotori terutama oleh Ignaz Goldziher dan Joseph Schacht, merupakan benchmark bagi kajian-kajian serupa dalam tradisi orientalis. Schacht dan Goldziher menyatakan bahwa dari masa Nabi hingga abad pertama hijrah, hukum Islam seperti yang kita kenal saat ini belum terbentuk.

Walaupun al-Qur'an telah meletakkan dasar-dasar hukum keluarga, kewarisan dan ibadah ritual tertentu, generasi pertama umat Islam tidak terlalu memperdulikan aturanaturan tersebut, sehingga dalam berbagai kasus, praktik hukum pada masa awal Islam telah menyimpang dari ketentuan harfiah alQur'an. Selama periode formatifnya, hukum Islam memiliki kelenturan yang luar biasa dalam menyerap dan mengadaptasikan gaga- san dan unsur-unsur asing, sehingga bentuk aslinya sulit untuk dikenali.

Mengenai hadis Nabi, para orientalis umumnya berpendapat bahwa hadis dalam arti berita atau riwayat yang dikatakan berasal dari Nabi baru muncul pada akhir abad pertama hijrah, dan dasar-dasar hukum Is lam yang kita kenal sekarang tidak dibangun oleh Nabi dan para sahabatnya, tapi oleh para qadi yang dipilih dan diangkat oleh penguasa Bani Umayyah.

Para qadi itu kemudian menyusupkan praktik-prektek populer administrasi pemerintahan bani Umayyah ke dalam hukum Islam. Selama dekade pertama abad kedua hijrah, qadi yang semakin banyak jumlahnya itu kemudian menyatukan diri ke dalam sebuah mazhab hukum klasik yang didasarkan pada letak geografis.

Untuk mendapatkan pembenaran atas pendapat mereka, para ahli hukum kemudian melakukan proyeksi ke belakang terhadap hadis dan menghubung-hubungkannya dengan tokoh penting dari periode sebelumnya, kemudian kembali dihubungkan dengan tokohtokoh sahabat, dan akhirnya dihubungkan kepada Nabi.

Kemudian selama masa Syafi'i (w. 204 H/820 M), sebagai akibat dari usahanya, nilai hadis formal mulai menyingkirkan "tradisi yang hidup" yang dianut oleh mazhabmazhab hukum klasik. Hal ini mengakibatkan munculnya hadis-hadis palsu lengkap dengan sanad fiktif yang bersambung hingga Nabi.

Dengan demikian teori tentang isnad hadis yang berkembang dalam tradisi kesarjanaan Barat sebagian besar, kalau tidak ingin dikatakan seluruhnya, telah dibangun untuk pertama kalinya oleh Goldziher sebagai perintisnya dan kemudian diformulasikan dengan lebih terperinci oleh Schacht, yang menyodorkan dua tesis utamanya:

Pertama, kebiasaan menyebutkan sanad hadis yang diproyeksikan ke belakang hingga masa Nabi baru dimulai pada abad ke-2 hijrah; yang berarti bahwa tradisi penyebutan sanad merupakan hal yang muncul belakangan, dan kedua, semakin terperinci dan terlihat rapi sanadnya secara formal, semakin je- 
las kepalsuan sanad tersebut. Sehingga kesimpulan akhir teori Schacht tentang hadis secara umum adalah bahwa tidak ada satupun

\section{DAFTAR PUSTAKA}

Goldziher, Ignaz, Introduction to Islamic Theology and Law, New Jersey: Princeton University Press, 1981.

Schacht, Joseph, The Origins of Muhammadan Jurisprudence, Oxford: Clarendon Press, 1979.

, An Introduction to Islamic Law, Oxford: Clarendon Press, 1986.

, "Pre-Islamic Background and Early Development of Jurisprudence," dalam Law in the Middle East: Origin and Development of Islamic Law, Majid Khadduri dan Herbert J. Liebesny (eds.), Washington DC: The Middle Eastern Institute, 1955.

, "The School of Law and Later Development of Jurisprudence," hadis yang benar-benar berasal dari Nabi, walaupun kemungkinan ada beberapa hadis yang berakar pada ajarannya.

dalam Law in the Middle East: Origin and Development of Islamic Law, Majid Khadduri dan Herbert J. Liebesny (eds.), Washington DC: The Middle Eastern Institute, 1955.

Izutsu, Toshihiko, Ethico-Religious Concepts in the Quran, Montreal: McGill University Press, 1966.

Anderson, J.N.D., Islamic Law in the Modern World, New York: New York State University Press, 1959. , Law Reform in the Muslim World, London: The Athlone Press, 1976.

, 'Recent Development in Shari'ah Law," dalam Muslim World 40-41, 1950-1951. 